\title{
3D culture of adult mouse neural stem cells within functionalized self-assembling peptide scaffolds
}

This article was published in the following Dove Press journal:

International Journal of Nanomedicine

29 April 201 I

Number of times this article has been viewed

\section{Carla Cunha' ${ }^{1,2}$ \\ Silvia Panseri ${ }^{3,4}$ \\ Omar Villa ${ }^{1,2}$ \\ Diego Silva ${ }^{1,2}$ \\ Fabrizio Gelain ${ }^{1,2}$ \\ 'Department of Biotechnology and Biosciences, University of Milano- Bicocca; ${ }^{2}$ Center for Nanomedicine and Tissue Engineering, CNTE - A.O. Ospedale Niguarda Ca' Granda, Milan; ${ }^{3}$ Laboratory of Biomechanics and Technology Innovation, Rizzoli Orthopaedic Institute, Bologna; ${ }^{4}$ Laboratory of Nano-Biomagnetism, Institute of Science and Technology for Ceramics, National Research Council, Faenza, Italy}

Correspondence: Carla Cunha,

Fabrizio Gelain

Department of Biotechnology and Biosciences, University of Milano-Bicocca, Piazza della Scienza 2 , 20126 Milan, Italy

Tel +390264483312

Fax +390264483314

Email c.cunha@garvan.org.au;

fabrizio.gelain@unimib.it

\begin{abstract}
Three-dimensional (3D) in vitro models of cell culture aim to fill the gap between the standard two-dimensional cell studies and the in vivo environment. Especially for neural tissue regeneration approaches where there is little regenerative capacity, these models are important for mimicking the extracellular matrix in providing support, allowing the natural flow of oxygen, nutrients, and growth factors, and possibly favoring neural cell regrowth. We have previously demonstrated that a new self-assembling nanostructured biomaterial, based on matrigel, was able to support adult neural stem cell (NSC) culture. In this study, we developed a new 3D cell culture system that takes advantage of the nano- and microfiber assembling process, under physiologic conditions, of these biomaterials. The assembled scaffold forms an intricate and biologically active matrix that displays specifically designed functional motifs: RGD (Arg-Gly-Asp), BMHP1 (bone marrow homing peptide 1), and BMHP2, for the culture of adult NSCs. These scaffolds were prepared at different concentrations, and microscopic examination of the cell-embedded scaffolds showed that NSCs are viable and they proliferate and differentiate within the nanostructured environment of the scaffold. Such a model has the potential to be tailored to develop ad hoc designed peptides for specific cell lines.
\end{abstract}

Keywords: biomaterials, tissue engineering, 3D in vitro model

\section{Introduction}

Nowadays, tissue engineering is one of the most promising areas of research due to its potential to regenerate damaged or lost tissues. Nerve regeneration in particular has been the focus of much research in the last decade, particularly for its potential application in neurodegenerative diseases such as Parkinson's and Alzheimer's disease, or in spinal cord injury. ${ }^{1-4}$ Clinical results are still far from being noteworthy. The in vitro techniques instead are many, and various attempts have been made to culture different cell types in three-dimensional (3D) microenvironments, in different areas of tissue engineering. A recent review has addressed most of them, ${ }^{5}$ but other examples include studies where primary hepatic cells were shown to recover a tissue-specific mechanochemical characteristic either embedding them in matrigel or collagen I or culturing them as 3D aggregates. ${ }^{6,7}$ Also, fibroblasts cultured in 3D collagen were found to have a different shape ${ }^{8}$ and a different distribution of transmembrane adhesion proteins ${ }^{9,10}$ than those grown on two-dimensional (2D) substrates. When used as a model of epithelial organ development, Madin-Darby canine kidney cells generated polarized spherical and tubular monolayers resembling rudimentary epithelial suborgans when cultured within 3D collagen scaffolds, whereas they become only partially polarized when cultured on flat supports. ${ }^{1-14}$ Very recently, cells derived from 
normal and diseased kidney were cultured in 3D porous silk scaffolds and further extended into a perfusion bioreactor. A structural and functional kidney-like tissue was obtained. ${ }^{15}$ Also recently, a 3D model of osteogenesis was developed by culturing bone marrow explants and allowing for inherent ossification of bone marrow tissue. ${ }^{16}$

In particular for the peripheral and central nervous system, a few 3D approaches have been proposed, but more and improved models will have to be developed before effective output in neural tissue engineering will be achieved. Examples include a 3D model for peripheral nerve regeneration, using a highly oriented $3 \mathrm{D}$ collagen scaffold to promote directed axonal growth, with dorsal root ganglia explants. ${ }^{17}$ Another study used a collagen and hyaluronan scaffold to grow embryonic, postnatal, and adult neural stem and progenitor cells. ${ }^{18}$ Early differentiating human embryonic stem cells were further induced to differentiate in a 3D scaffold made of poly(lactic-co-glycolic acid)/poly(L-lactic acid). ${ }^{19}$ Finally, one study compared the viability of hippocampal neurons and astrocytes grown on 2D conditions with that of cells grown on an aragonite $3 \mathrm{D}$ scaffold prepared from coralline exoskeleton, showing better results for the $3 \mathrm{D}$ cultures. ${ }^{20}$

For tissue engineering purposes, the nature of the scaffold is a key concern, since it will provide cell support and allow for exchanges between cells and medium, of oxygen, nutrients, growth factors, and cytokines. In trying to reproduce the extracellular matrix (ECM) conditions, such biomimetic scaffolds need to display a series of characteristics: biodegradability and absence of immune response by the host tissue, appropriate mechanical properties, appropriate porosity and permeability and, finally, they need to be produced on a large scale and in a reproducible way. ${ }^{5}$ One of the main difficulties of many 3D culture systems is obtaining the appropriate internal organization of the scaffold. In order to have cells in a truly $3 \mathrm{D}$ microenvironment, the dimensions of the scaffold fibers and pores must be substantially smaller than the cells, so that cells are fully surrounded by the scaffolds, much like the in situ cytoarchitecture. Moreover, most of the scaffolds used so far are either made from synthetic polymers, such as polyethylene glycol, which present very limited cellular recognition motifs therefore hindering cell-scaffold interaction, or naturally derived polymers, such as collagen, that often present residual undefined or nonquantified elements. ${ }^{9}$ New classes of biomaterials are presently being developed, in order to overcome most of these problems. This work presents a recently introduced class of biomaterials with potential for tissue engineering: functionalized self-assembling peptides (SAPs).
SAPs are a recent class of biosynthetic materials with potential use in the development of scaffolds for 3D cell cultures. $^{21,22}$ Various SAPs have successfully been used for neural cell culture. An amphiphilic molecule containing the IKVAV (isoleucine-lysine-valine-alanine-valine) motif, an epitope derived from laminin, has been shown to encourage differentiation of neural progenitor cells into neurons. ${ }^{23}$ RADA16-like SAPs are composed of natural amino acids that spontaneously self-assemble under physiologic conditions into antiparallel $\beta$-sheets forming nano- and microfibers that closely mimic the architecture of the ECM. RADA16-I and RADA16-II have been shown to induce neurite outgrowth and synapse formation, using pheochromocytoma 12 (PC12) cells. ${ }^{24}$ RADA16-I has been shown to favor proliferation and differentiation of neural stem cells (NSCs), ${ }^{25}$ to attract migrating hippocampal neural cells, which are potential neuroprogenitors at the interface between hippocampal slices and the biomaterial, ${ }^{26}$ and recently to enhance neurite outgrowth on a PC12 cell line. ${ }^{27}$ RADA16-I has also been shown to induce osteoblast proliferation, differentiation, and migration. ${ }^{28}$

The most used SAP for scope of neural cell culture is RADA16-I, which is a 16-residue peptide composed of alternating hydrophilic arginine, hydrophobic alanine, and hydrophilic aspartic acid (RADARADARADARADA). They consist of $>99 \%$ water content and are made of peptide molecules that can break down into natural amino acids, which can potentially be used by the cells. RADA16-I can be synthesized commercially with high purity and, importantly, it can be custom-tailored in order to incorporate functional motifs for specific cell culture applications, be it for neural cells or others.

In our previous work, we designed and synthesized RADA16-I with different functional motifs. ${ }^{25,39}$ We demonstrated how the hydrophilic-hydrophobic balance of the inserted functional motifs may influence the $\beta$-sheet formation propensity of the SAPs. Indeed functional motifs comprising clustered hydrophobic residues can cause hydrophobic collapse of the monomers, preventing their assembling into $\beta$-sheets, and, on the other hand, in the case of too many hydrophilic residues, the overall double-layered structure of RADA16-I could be destabilized. ${ }^{39}$ Nonetheless, when proper functional motifs are chosen, as in this work, the tabular nanofibers generated by RADA16 are comparable in size and structure to the fibers formed by functionalized RADA16 peptides, yielding a nanostructured scaffold when dissolved in phosphate buffered saline (PBS) which are comparable in size and shape to animal extracts like matrigel. In 
particular, fiber width may vary from $10 \mathrm{~nm}$ for RADA16 to $13-15 \mathrm{~nm}$ for functionalized RADA16, depending on the sequence length, ${ }^{39}$ as the flagging functional motif increases the width of the fibers. ${ }^{25,28}$ Lastly, these scaffolds are characterized by the presence of pores 5-200 $\mathrm{nm}$ in width; ideal for migration, differentiation, and proliferation of NSCs. ${ }^{25}$

In the last decades, NSCs have been the focus of much research and attention for tissue engineering purposes due to their capacity to potentially regenerate all the major cellular phenotypes at the site of neural tissue injury (multipotentiality), without inducing an immune response, due to their inherent/ defining undifferentiated state. ${ }^{29,30}$ Moreover, they are able to replicate indefinitely in vitro, maintaining a stable profile, ${ }^{31}$ so they are a potential renewable source of cell lineages from the CNS.

While most of the research on biomaterials scaffold for tissue engineering resides on the fabrications of the biomaterial itself, few have analyzed them as a whole with a cellular component. In this study, we used RADA16-I-based SAPs that incorporate the ubiquitin receptor binding site RGD (Arg-Gly-Asp) ${ }^{32}$ functional motif (RADA16-RGD) and also the laminin-derived motifs BMHP1 (RADA16-BMHP1) and BMHP2 (RADA16-BMHP2), ${ }^{33}$ together with pure RADA16-I. Our aim was to successfully seed and culture NSCs in a 3D biomaterial scaffold and to determine the best conditions for their proliferation and differentiation.

\section{Materials and methods}

\section{Biomaterial synthesis and purification}

The functionalized SAPs were synthesized by Fmoc solidphase method, using a Liberty Microwave Peptide Synthesizer (CEM, Matthews, NC). All amino acids were purchased in their protected forms (Novabiochem, Darmstadt, Germany) and a Rink amide p-methylbenzhydrylamine (MBHA) resin (Sigma-Aldrich, St Louis, MO) was used. The N-terminal of each peptide was acetylated by acetic anhydride and cleavage performed by reagent $\mathrm{K}$. The cleaved product was precipitated and washed with diethyl ether multiple times. The product was then dissolved in $\mathrm{H}_{2} \mathrm{O} / \mathrm{CH}_{3} \mathrm{CN}(60 / 40 \mathrm{v} / \mathrm{v})$ and lyophilized (Labconco, Kansas City, MO). Trifluoroacetic acid salts, arising from synthesis and purification of SAP were replaced with chloride salts via dissolution in $\mathrm{HCl}$. The molecular weight of the peptide was verified by MALDI-TOF mass spectrometry (Applied Biosystems, Carlsbad, CA). The crude peptide was purified in a $\mathrm{CH}_{3} \mathrm{CN} /$ water gradient, using a reverse phase Waters HPLC (Milford, MA) equipped with an analytical and semi-preparative BioBasic C4 $300 \AA$ (Thermo Scientific, Waltham, MA). The purified product was lyophilized. The purity of the final product was calculated to be $>99 \%$.

RADA16-I (PuraMatrix ${ }^{\text {TM }}$ Peptide Hydrogel; BD Biosciences, Franklin Lakes, NJ) was lyophilized. All functionalized SAPs and RADA16-I were dissolved in sterile distilled $\mathrm{H}_{2} \mathrm{O}$ (GIBCO, Invitrogen, Carlsbad, CA) to the desired concentrations $(0.5 \%, 1 \%$, and $2 \%(\mathrm{w} / \mathrm{v}))$ and sonicated (S30H Elmasonic; ELMA, Singen, Germany) for 30 minutes before use.

\section{Scanning electron microscopy scaffolds characterization}

Scaffolds were imaged and characterized using a JEOL JSM-6060 Scanning Electron Microscope (SEM) (Tokyo, Japan). Samples were coated with $10 \mathrm{~nm}$ of $\mathrm{Au} / \mathrm{Pd}$ using a Polaron Range sputter coater (DentonVaccum, Moorestown, NJ) prior to imaging. Samples were soaked in $5 \%$ glutaraldehyde at $4{ }^{\circ} \mathrm{C}$ for 2 hours, washed in Milli-Q water, slowly dehydrated in $10 \%$ increment steps of ethanol for 5 minutes each, and placed in a pressurized liquid $\mathrm{CO}_{2}$ /siphon for 1 hour using a $\mathrm{CO}_{2}$ critical point dryer (Tousims, USA). Scaffolds were next sputter-coated using a Polaron Range sputter and mounted on a copper grid to be examined with the same SEM.

\section{Adult NSC isolation and culture}

The NSCs used in this work were extracted from the subventricular zone (SVZ) of 8-week-old male C57BL/6 commercial mice (Charles River Laboratories, Wilmington, MA) and expanded in a basal cell culture medium, as described previously ${ }^{34-37}$ Briefly, mice were sacrificed by cervical dislocation, and the brains were microdissected by use of a stereomicroscope. The SVZ was isolated, and tissue was mechanically and enzymatically (papain + DNAse) fragmented. A singlecell suspension was obtained by subsequence centrifugation steps and cultured at $37^{\circ} \mathrm{C}, 5 \% \mathrm{CO}_{2}$. NSCs were isolated by direct formation of neurospheres, expanded by mechanical dissociation, and characterized for their staminality. NSCs were cultured in Dulbecco's Modified Eagle Medium: Nutrient Mixture F-12 (DMEM/F-12) serum-free medium containing $20 \mathrm{ng} / \mathrm{mL}$ of epidermal growth factor (EGF) (Peprotech, Rocky Hill, NJ) and $10 \mathrm{ng} / \mathrm{mL}$ of fibroblast growth factor (FGF)-2 (Peprotech), passaged every 4/5 days when the neurospheres reached diameters of near $200 \mu \mathrm{m}$ and seeded in $75 \mathrm{~cm}^{2}$ tissue culture flasks (Corning, Inc, Corning, NY) at a concentration of $10^{4} \mathrm{cells} / \mathrm{cm}^{2}$. All NSCs used in this study were between passage 10 and 15 . All cell-handling procedures were performed in a sterile laminar flow hood. All cells used 
in this work were used 2 days after the last mechanical dissociation in order to obtain the maximum percentage of NSCs. European Commission guidelines (EC Council 86/609, 1986) and Italian legislation (Decreto L.vo 116/92) for the care and use of laboratory animals have been observed.

\section{D NSC seeding on SAP}

We diluted SAPs with sterile distilled water (GIBCO, Invitrogen) to double the desired concentration the day before cell plating. We coated a 96-well plate with Cultrex $^{\circledR}$ basement membrane extract (R\&D Systems, Minneapolis, MN) to serve as a control. The next day, $25 \mu \mathrm{L}$ of each SAP was diluted with $25 \mu \mathrm{L}$ of glucose $8 \%$, in order to cope with the cellular osmolarity ( $\sim 260-320 \mathrm{mOsm} / \mathrm{L})$. We coated a 96-well plate with $50 \mu \mathrm{L} /$ well of the peptide solution and left at $37^{\circ} \mathrm{C}$ for 10 minutes. We then added $100 \mu \mathrm{L}$ of basal medium to each well and allowed the SAPs to assemble at $37^{\circ} \mathrm{C}$ for 30 minutes. The medium was gently replaced, and 5000 cells/well were plated on the top surface of each SAP and Cultrex ${ }^{\circledR}$ substrate.

\section{D scaffold preparation and NSC encapsulation}

The 3D scaffold was self-assembled on cell culture inserts, polyethylene terephthalate (PET) track-etched membrane, $1.0 \mu \mathrm{m}$ pore size (BD Biosciences), in Multiwell 24 Well (BD Biosciences). We diluted SAPs with sterile distilled water (GIBCO, Invitrogen) to double the desired concentration the day before cell plating. On the day of scaffold preparation, $12 \mu \mathrm{L}$ of each SAP was diluted with $12 \mu \mathrm{L}$ of glucose $8 \%$, in order to cope with the cellular osmolarity ( 260-320 $\mathrm{mOsm} / \mathrm{L})$, to the final desired concentration. A volume of $24 \mu \mathrm{L}$ of each SAP was gently mixed with $8 \mu \mathrm{L}$ of culture medium containing a cell density of 4000 cells $/ \mu \mathrm{L}$, in a total of $3.2 \times 10^{4}$ cells. The mixture was placed on the insert membrane, which in turn was placed in the well containing basal cell culture medium for the proliferation assay and basal cell culture medium supplemented with $20 \mathrm{ng} / \mathrm{mL}$ leukemia inhibitory factor (LIF) (Chemicon, Millipore, Temecula, CA) and $20 \mathrm{ng} / \mathrm{mL}$ brain-derived neurotrophic factor (BDNF) (Peprotech) for cell differentiation and allowed to self-assemble at $37^{\circ} \mathrm{C}$. The culture medium was replaced every 3 days. All images were acquired using an inverted microscope (Axiovert; Zeiss, Oberkochen, Germany).

\section{Cell proliferation assay}

The MTS assay was performed as described in the CellTiter 96 AQueous One Solution Cell Proliferation Assay (Promega, Madison, WI). Briefly, cells were incubated for 3.5 hours with $20 \mu \mathrm{L}$ of cell titer reagent, at $37^{\circ} \mathrm{C}$, together with known cell concentrations, from 1000 to 40,000 cells/well. In this assay, the metabolically active cells react with the tetrazolium salt in the MTS reagent to produce a formazan dye that can be observed at $\lambda_{\max }$ of $490 \mathrm{~nm}$, using a $\mathrm{V}_{\max }$ microplate reader (Molecular Devices, Sunnyvale, CA). This absorbance is directly proportional to the number of viable cells. Mean values of absorbance were determined and a standard curve of absorbance versus cell concentration was created, from which the cell concentration values for each sample were determined.

\section{Quanti-iT PicoGreen ${ }^{\circledR}$ Assay}

The PicoGreen assay was performed as described in the Quanti-iT ${ }^{\mathrm{TM}}$ PicoGreen $^{\circledR}$ dsDNA Assay Kit (Molecular Probes; Invitrogen). Briefly, cells were collected and digested with proteinase K (Sigma-Aldrich) at a final concentration of $20 \mu \mathrm{g} / \mathrm{mL}$ in $1 \mathrm{~mL}$ of sodium citrate buffer $50 \mathrm{mM}$, at $60^{\circ} \mathrm{C}$ overnight. A DNA standard curve was prepared, with DNA standards from $1 \mathrm{ng} / \mathrm{mL}$ to $1 \mu \mathrm{g} / \mathrm{mL}$. A volume of $1 \mathrm{~mL}$ of Quanti-iT ${ }^{\mathrm{TM}}$ PicoGreen $^{\circledR}$ reagent was added to each sample and standard and incubated for 5 minutes. Fluorescence was measured using a fluorescence microplate reader: excitation, $475 \mathrm{~nm}$; emission, $535 \mathrm{~nm}$ (Tecan, Männedorf, Switzerland). Mean values of arbitrary fluorescence units (AFU) were measured, and a standard curve of fluorescence versus DNA concentration was created, from which the DNA concentration values for each sample were determined.

\section{Immunofluorescence}

Differentiated cells were fixed in $4 \%(\mathrm{w} / \mathrm{v})$ paraformaldehyde after 7 days in culture. Blocking was performed with $20 \%$ normal goat serum and tissue permeabilization with $0.3 \%$ (v/v) Triton $\mathrm{x}-100$. Cells were incubated overnight at $4^{\circ} \mathrm{C}$, with the following antibodies: mouse anti-neuronal Class III $\beta$-Tubulin (TUJ1, 1:400) (Covance, Princeton, NJ), rabbit anti-glial fibrillary acidic protein (GFAP, 1:500) (Dako, Glostrup, Denmark), mouse anti-galactocerebroside C (GalC, 1:200) (Chemicon, Millipore) and mouse anti-oligodendrocyte marker O4 (1:200) (Chemicon, Millipore). Primary antibodies were probed with the secondary antibodies Alexa Fluor 488 goat anti-rabbit (1:500) (Molecular Probes, Invitrogen) and Cy3 goat anti-mouse (1:1000) (Jackson ImmunoResearch, West Grove, PA), for 45 minutes at room temperature. Cell nuclei were stained with 4'-6-diamidino-2-phenylindole (DAPI) (Molecular 
Probes, Invitrogen). Sections were examined by an upright (Axioplan; Zeiss) or inverted fluorescence microscope (Axiovert; Zeiss).

\section{Rheological analysis}

AAR2000 shear type oscillatory rheometer (TA Instruments, New Castle, DE) was used for the analysis. For each SAP, a sample of $40 \mu \mathrm{L}$, at concentrations of $0.5 \%, 1 \%$, and $2 \%$, was positioned on the Peltier plate, PBS $1 \mathrm{X}$ was added around the sample, and 30 minutes allowed for the SAP to self-assemble. A frequency sweep test was performed for each sample, in a range of frequencies from 1 to $100 \mathrm{rad} / \mathrm{sec}$. Each test was performed at $37^{\circ} \mathrm{C}$ using a $20 \mathrm{~mm}, 0.5^{\circ}$ cone geometry, with a truncation gap of $34 \mu \mathrm{m}$. Elastic shear modulus $\left(G^{\prime}\right)$ and viscous shear modulus ( $\left.G^{\prime \prime}\right)$ were determined for each angular frequency value.

\section{Statistical analysis}

Each experiment was performed in triplicate unless otherwise indicated. All results were expressed as mean \pm standard error of the mean (sem) plotted on graph. Analysis of differences between samples was made by one-way ANOVA followed by the Tukey multiple comparisons test, with statistical significance set at $P \leq 0.05$, by use of GraphPad Prism software (v 5.0; La Jolla, CA).

\section{Results}

The functionalized SAPs used in this work have been synthesized and purified in our laboratory and have been described and characterized in our previous works. ${ }^{25,38,39}$ They were analyzed here in parallel with RADA16-I (PuraMatrix ${ }^{\mathrm{TM}}$ Peptide Hydrogel; BD Biosciences). A summary of the four SAPs used can be found in Table 1. These SAPs consist of $99 \%$ water and are composed of less than 30 alternating hydrophobic and hydrophilic residues that spontaneously assemble into double-layered antiparallel $\beta$-sheets under suitable physiologic conditions. Upon exposure to neutral $\mathrm{pH}$ liquids, these organizations form nanostructured scaffolds that mimic the ECM. $^{40,41}$

\section{D NSC proliferation on different SAPs}

Cell quantification using the MTS cell proliferation assay was performed in order to determine the extent of NSC proliferation and viability on SAPs. We coated 96-well plates with each of the SAPs in Table 1, diluted at $2 \%, 1 \%$, and $0.5 \%$. A total of 5000 cells were plated on each and grown on basal medium supplemented with basic fibroblast growth factor (bFGF) and EGF. We used Cultrex ${ }^{\circledR}$ substrate coating as a positive control. After 5 days in culture, the MTS assay was performed for the direct evaluation of the total number of live cells present in culture. Within each experiment, we also plated 1,000, 5,000, 10,000, 20,000, and 40,000 cells for the calibration curve. Results are presented in Figure 1 as mean \pm sem of three independent experiments. As we can see, for all the SAP scaffolds used, the total number of viable cells is around six times higher than the number of cells plated (5000), meaning that they all have a positive effect on cell proliferation and survival. Still, there is not a significant difference in the result between SAP scaffolds used, and they all performed worse than the control condition, coated with Cultrex ${ }^{\circledR}$.

\section{NSCs can be cultured within 3D SAP scaffolds}

These scaffolds are made of nanofibers and pores with dimensions 10-100 times smaller than those of cells, so that cells enclosed within are in a true $3 \mathrm{D}$ environment. Moreover, the functionalized SAPs used for the scaffold have already been demonstrated to be able to support NSC growth ${ }^{25}$ and to be able to release active cytokines in a slow and sustained manner, ${ }^{44}$ making them ideal candidates for 3D NSC culture and future use in tissue engineering applications. These SAPs have the characteristic of being soluble in aqueous solutions and assembling into nanofiber scaffolds upon exposure to physiologic $\mathrm{pH}$ solutions such as the NSC culture medium. We have therefore developed a culture system in which cells are mixed with the SAPs and immediately placed in contact with culture medium in order to allow assembly of the scaffolds with embedded cells (see Materials and methods for details). A schematic representation of the culture setup

Table I Different self-assembling peptide hydrogels used in this study

\begin{tabular}{|c|c|c|c|}
\hline SAP & Sequence & Origin of functional motif & Study \\
\hline RADAI6-I-BMHPI & Ac-(RADA) ${ }_{4}$-GGPFSSTKT-NH ${ }_{2}$ & BMHP & Nowakowski et $\mathrm{al}^{33}$ \\
\hline RADA I6-I-BMHP2 & Ac-(RADA)-GGSKPPGTSS-NH ${ }_{2}$ & $\mathrm{BMHP}$ & Nowakowski et $\mathrm{al}^{33}$ \\
\hline RADAI6-I-RGD & Ac-(RADA) $)_{4}$-GPRGDSGYRGDSG-NH ${ }_{2}$ & Collagen VI & $\begin{array}{l}\text { Ruoslahti and Pierschbacher } \\
\text { Schense et } \text { al }^{42}\end{array}$ \\
\hline RADA I6-I & $\left(\mathrm{RADA}_{4}\right.$ & - & Zhang et $\mathrm{al}^{43}$ \\
\hline
\end{tabular}

Abbreviations: BMHP, bone marrow homing peptide; RGD, Arg-Gly-Asp. 


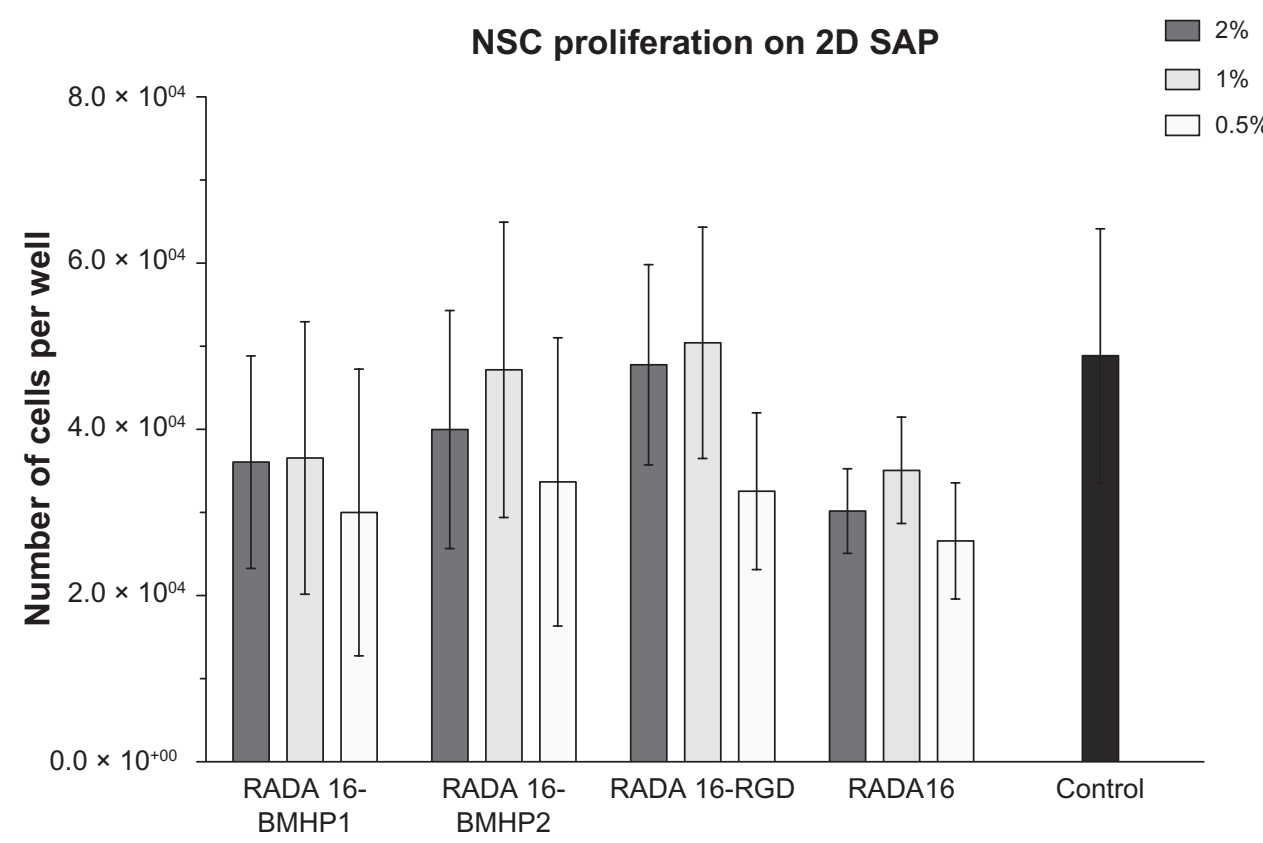

Figure I NSCs were grown on different functionalized biomaterial supports: RADAI6-BMHPI, RADAI6-BMHP2, and RADAI6-RGD, and also on RADAI6, at different dilutions. Control condition refers to NSCs grown on Cultrex ${ }^{\circledR}$ substrate. Proliferation was evaluated by use of the MTS assay, and results are expressed as mean \pm standard error of the mean of total number of cells after 5 days in culture $(n=3)$.

Abbreviations: 2D, two-dimensional; BMHP, bone marrow homing peptide; NSC, neural stem cell; RGD, Arg-Gly-Asp; SAP, self-assembling peptide.

can be found in Figure 2, as well as two examples of NSC behavior and morphology within 3D SAP scaffolds.

\section{Evaluation of NSC proliferation within different 3D SAP scaffolds}

NSCs were grown on different biomaterial 3D supports: functionalized SAPs RADA16-BMHP2, RADA16-BMHP1, RADA16-RGD, and RADA16. All of them were diluted at $2 \%, 1 \%$, and $0.5 \%(\mathrm{w} / \mathrm{v})$. Control condition refers to cells grown on Cultrex ${ }^{\circledR}$ substrate on a 24 -well plate. The same initial number of cells was plated for each condition $(25,000)$ and control and NSCs were left to proliferate for 5 days. Brightfield images for each condition were acquired via an inverted microscope at 5 days after seeding and can be found in Figure 3. As we can observe, the typical neurospheres formed in $2 \mathrm{D}$ are not present in $3 \mathrm{D}$, this is due to the conformation of the scaffold in a nanofiber mesh. Also, some of the seeded cell planes are out of focus, overlapping the focused plane, resulting in a rather fuzzy image.

After 5 days in culture, total DNA in the scaffold was quantified by the PicoGreen Assay, as a measure of cell proliferation. We collected the whole 3D scaffold from the insert and the amount of cells present in the 24-well plate well for the 2D control. NSCs were digested with proteinase K overnight, and the following day the PicoGreen assay was performed. This assay measures double-stranded
DNA, and it is very sensitive even to low amounts of DNA as is the case of such a reduced number of cells. Results are presented in Figure 4 as mean \pm sem of four independent experiments performed. As we can observe, all three functionalized SAPs perform better than RADA16. In addition,
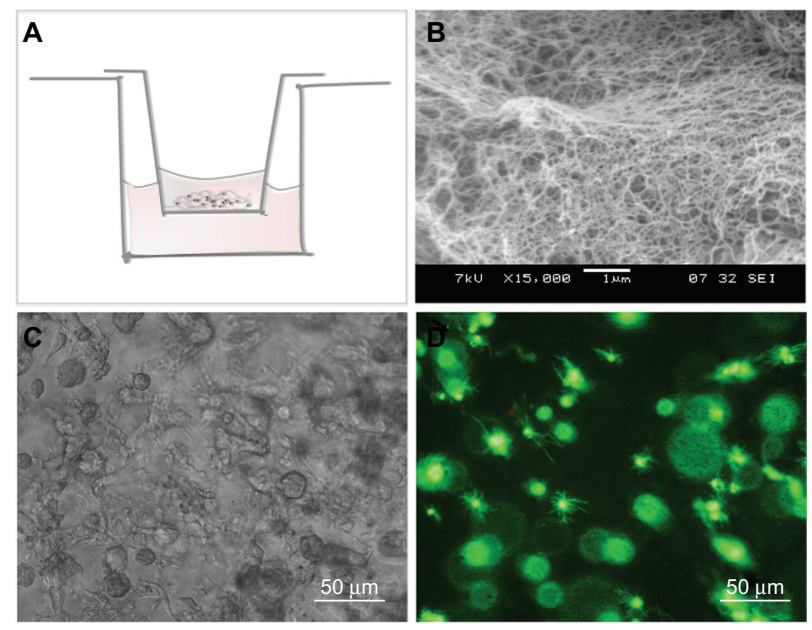

Figure 2 Three-dimensional NSC encapsulation within SAP scaffolds. A) Representation of the NSC/SAP scaffold assembling process. SAPs were mixed with NSCs and placed within a cell culture insert, which is then submerged in the culture medium. Scaffold assembling proceeds gradually as culture medium crosses the cell culture insert porous membrane. B) Scanning electron microscopy image of RADA16BMHP2. C) Brightfield image of NSCs cultured for 5 days on RADAI6-BMHP2. D) NSCs cultured for 7 days on RADA 16-BMHP2 and live cells stained with calcein acetoxymethyl $2 \mu \mathrm{M}$.

Abbreviations: BMHP, bone marrow homing peptide; NSC, neural stem cell; SAP, self-assembling peptide. 


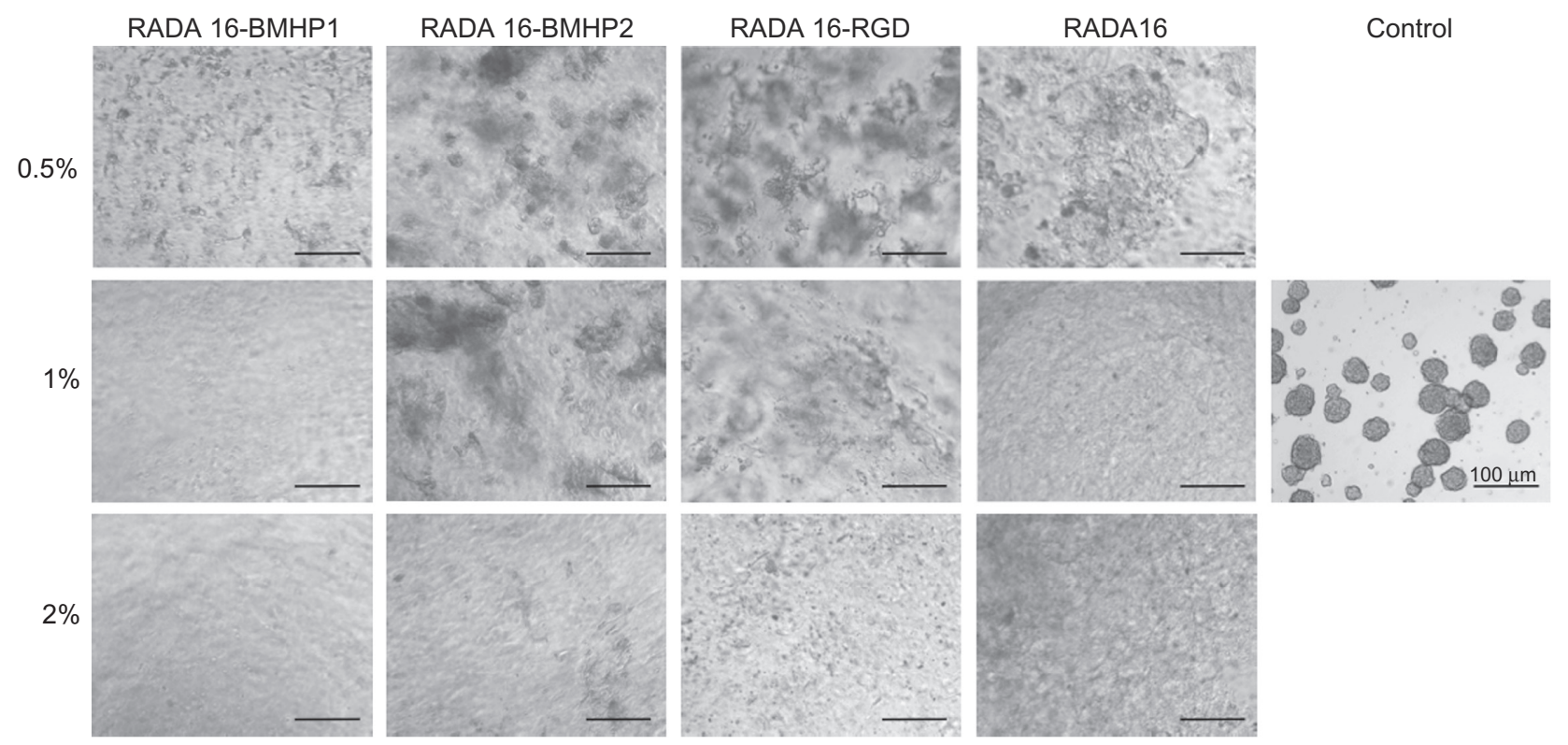

Figure 3 Brightfield images of NSCs within different SAP scaffolds, after 5 days in culture.

Abbreviations: BMHP, bone marrow homing peptide; NSC, neural stem cell; RGD, Arg-Gly-Asp; SAP, self-assembling peptide.

all SAPs and also RADA16 present higher proliferation rates when the SAP concentration is decreased, so that the best condition is when SAPs are used at $0.5 \%(\mathrm{w} / \mathrm{v})$. Still, cell proliferation in neither of the SAPs is as high as in the 2D control condition.

\section{Evaluation of the influence of each functional motif on NSC proliferation}

To further understand the influence of each functional motif on cell proliferation, we prepared different proportions of functionalized SAP and RADA16. Each functionalized SAP

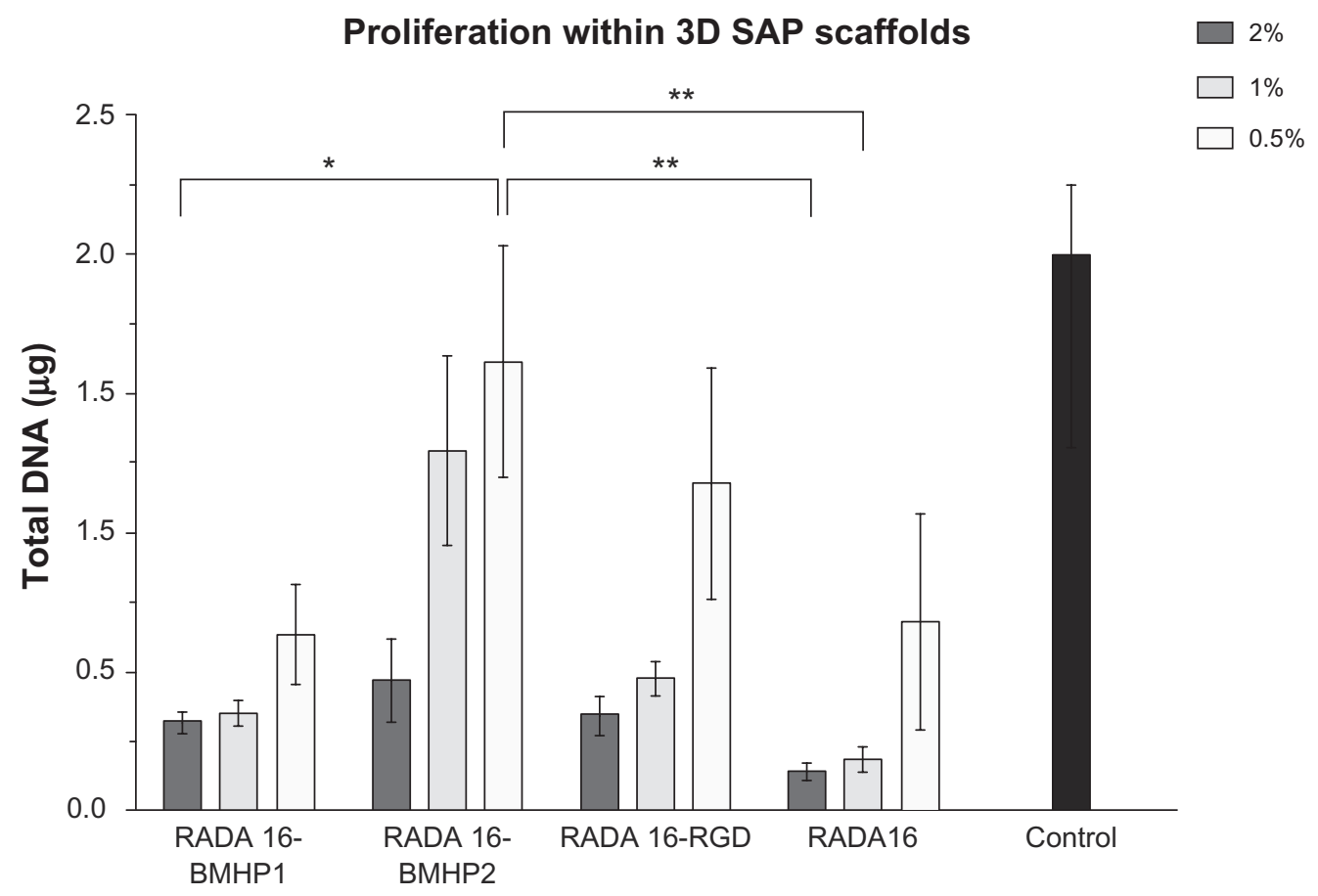

Figure 4 Proliferation of mouse NSCs within different 3D SAP scaffolds, quantified by use of the PicoGreen assay. Results are expressed as mean \pm standard error of the mean of total amount of DNA in the scaffolds and control after 5 days in culture $(n=4)$.

Notes: ${ }^{*} P \leq 0.05 ; * * P \leq 0.001$.

Abbreviations: 3D, three-dimensional; BMHP, bone marrow homing peptide; NSC, neural stem cell; RGD, Arg-Gly-Asp; SAP, self-assembling peptide. 
was mixed with RADA16 in proportions of 10:90, 50:50, and 90:10, maintaining a final concentration of SAP in solution of $0.5 \%(\mathrm{w} / \mathrm{v})$. This concentration was chosen because it performed the best in the previous experiment. A total of 25,000 cells were embedded in each SAP scaffold as previously described, and 25,000 cells were grown on Cultrex ${ }^{\circledR}$ substrate on a 24-well plate as a control condition. The same initial number of cells was plated for each condition and control and NSCs were allowed to proliferate for 5 days. Brightfield images for each condition were acquired 5 days after seeding using an inverted microscope and can be found in Figure 5A. After image acquisition, the PicoGreen assay was performed as described before, and the result for each condition is schematized in Figure 5B. As we can see, there are no significant differences between different proportions of the functionalized SAP with respect to the total amount of SAP.

\section{Evaluation of NSC multipotency after proliferation in 3D scaffolds}

To evaluate the capacity of NSC to generate differentiated progeny, NSC were cultured on the SAP scaffolds for 5 days as before. NSC were then collected and plated on Cultrex ${ }^{\circledR}$ coated coverslips and allowed to differentiate for 7 days. Immunofluorescence against neurons (TUJ1), astrocytes (GFAP) and oligodendrocytes ( $\mathrm{GalC}+\mathrm{O} 4)$ was performed

A

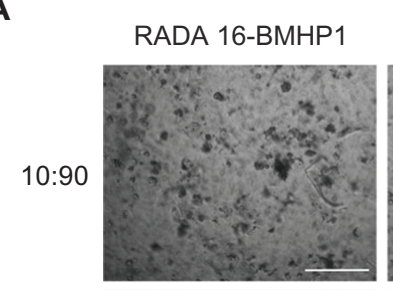

RADA 16-BMHP2

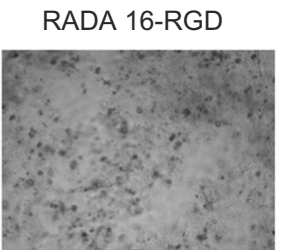

Control
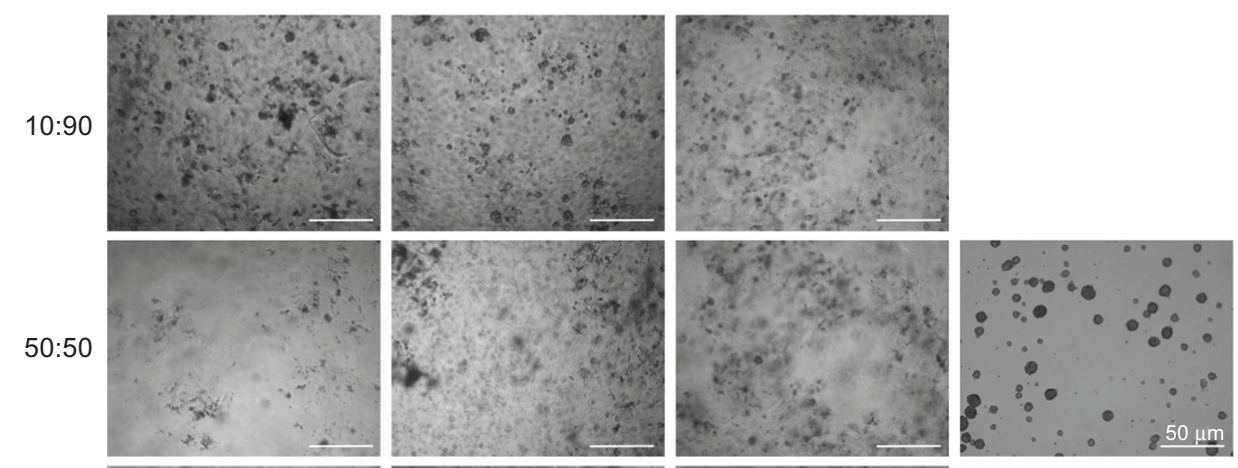

$90: 10$
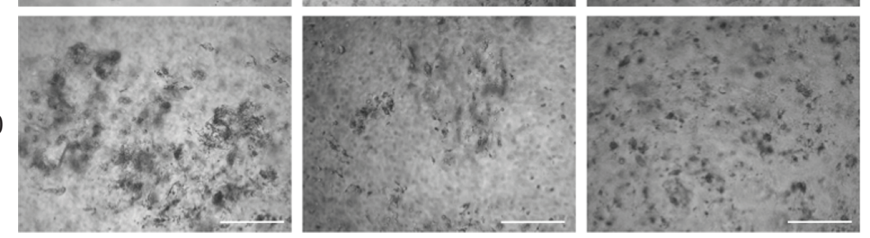

B

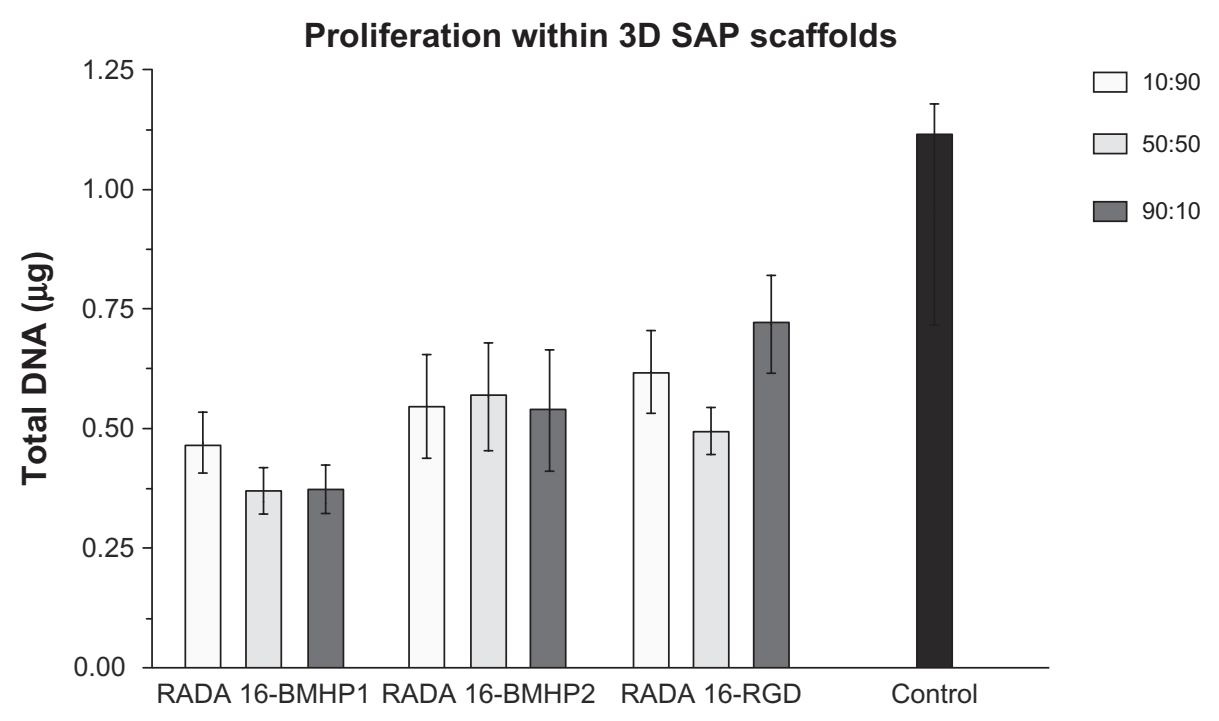

Figure 5 Proliferation of mouse NSCs within different 3D SAP scaffolds, quantified by use of the PicoGreen assay. A) Brightfield images were acquired after 5 days in culture. B) PicoGreen assay was performed after 5 days in culture, and results are expressed as mean \pm standard error of the mean of total amount of DNA in the scaffolds ( $n=4$ ). Abbreviations: 3D, three-dimensional; BMHP, bone marrow homing peptide; NSC, neural stem cell; RGD, Arg-Gly-Asp; SAP, self-assembling peptide. 
for each condition, and the total number of differentiated cells was determined as a percentage of the number of cells plated. Results are presented in Figure 6 as mean \pm sem of three independent experiments.

Results are presented as the number of cells differentiated and not percentage of TUJ1, GFAP, and GalC + O4 positive cells, since the morphology of the cells that had proliferated on SAPs in most of the cases could not be identified as neurons, astrocytes, or oligodendrocytes. As an example, we present in Figure 7 a GFAP staining for each SAP and control. For each condition, we can observe different cell morphology, indicating that each SAP scaffold influenced NSC differently. RADA16-RGD had the highest number of cells differentiated, and was significantly different from RADA16 $(P \leq 0.05)$ and RADA16-BMHP1 $(P \leq 0.001)$, indicating this scaffold presents a preferential environment for the maintenance of stem cell characteristics.

\section{Differentiation within the SAP scaffolds}

Differentiation within the scaffold was extremely difficult to quantify due to possible binding of the antibodies to the scaffold, but mostly due to the thickness of the sample, which could go up to $300 \mu \mathrm{m}$ (data not shown). This high number of scattering z-stacks in the sample poses a challenge to fluorescence microscopy, making a routine quantification very difficult. In Figure 8, we can see an example of differentiated NSCs marked with TUJ1 (red) and GFAP (green), after 7 days in 3D and 2D culture.

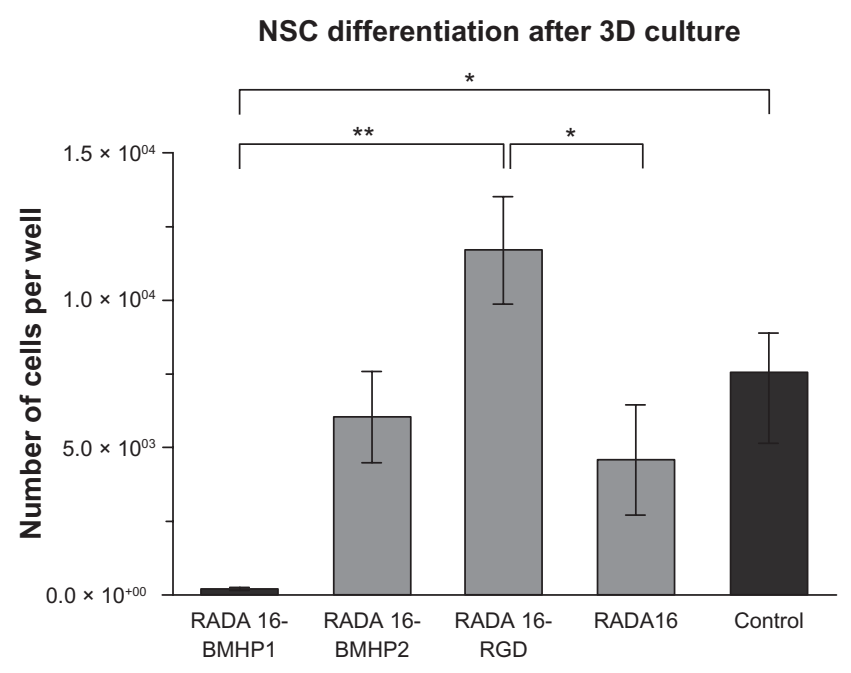

Figure 6 Evaluation of the capacity of mouse NSCs to differentiate after being grown on 3D scaffolds for 5 days. NSCs were collected from the scaffolds and induced to differentiate on Cultrex ${ }^{\circledR}$ coating for 7 days. The total number of cells differentiated in the well is presented as mean \pm standard error of the mean $(n=3)$.

Notes: $* P \leq 0.05 ; * * P \leq 0.001$.

Abbreviations: 3D, three-dimensional; BMHP, bone marrow homing peptide; NSC, neural stem cell; RGD, Arg-Gly-Asp.

\section{SAPs rheological characterization}

The possibility of modifying stem cell behavior by altering the mechanical properties of the 3D scaffold is very appealing for tissue engineering applications, and different studies have shown that stiffness of the substrate can influence and direct stem cell behavior. ${ }^{45,46}$ Here, we analyzed the viscoelastic characteristics of the SAPs RADA16-BMHP1, RADA16BMHP2, RADA16-RGD, and RADA16, at concentrations of $0.5 \%, 1 \%$, and $2 \%$, by performing a frequency sweep test between 1 and $100 \mathrm{rad} / \mathrm{sec}$. Elastic shear modulus G' and viscous shear modulus G" values were recorded, and the result for the mean of three independent analyses is presented in Figure 9A. The mean G' and G' values along the frequency sweep test was calculated for each condition, and the result is presented in Figure 9B. Our results show that, for each $\mathrm{SAP}$, increasing the concentration of the sample results in an increased G' modulus value along the frequency sweep test range. This parameter can be used as a direct measure of the substrate elasticity or stiffness, so that increased concentrations result in an increased stiffness of the scaffold. Also, G' values remain relatively constant throughout the test, so that all four scaffolds are very resistant to deformation. Moreover, we found that the mean G' value for all SAPs lies between 10 and $1000 \mathrm{~Pa}$ (RADA16-BMHP1 0.5\% 82.58, 1\% 134.81, 2\% 482.27; RADA16-BMHP2 0.5\% 58.99, 1\% 245.07, $2 \%$ 434.84; RADA16-RGD 0.5\% 41.53, 1\% 107.20, 2\% 233.13; RADA16 0.5\% 12.17, 1\% 36.81, 2\% 60.01), which has previously been demonstrated to be the optimum range for supporting NSC cultures. ${ }^{45}$

\section{Discussion}

In this study, we developed a 3D cell culture scaffold and assessed NSC survival, proliferation, and differentiation in this system. This scaffold is made of synthetic peptides that self-assemble into nanofibers, forming an intricate matrix that displays specifically designed functional motifs. Such a 3D support allows the transport of oxygen, nutrients, and waste products to take place in a $3 \mathrm{D}$ environment. We have made use of a recently introduced class of biomaterials, self-assembling peptides, which are based on a 16-residue peptide (RADA16) composed of alternating hydrophilic arginine, hydrophobic alanine, and hydrophilic aspartic acid that self-assembles into antiparallel $\beta$-sheets at physiologic $\mathrm{pH}$, forming nanofibers that mimic the architecture of the ECM. ${ }^{38,39}$ These biomaterials can be designed ad hoc to incorporate different functional motifs for different cell populations; they are biocompatible ${ }^{25,28,39}$ and able to sustainably release active cytokines. ${ }^{25}$ In this work, we have 


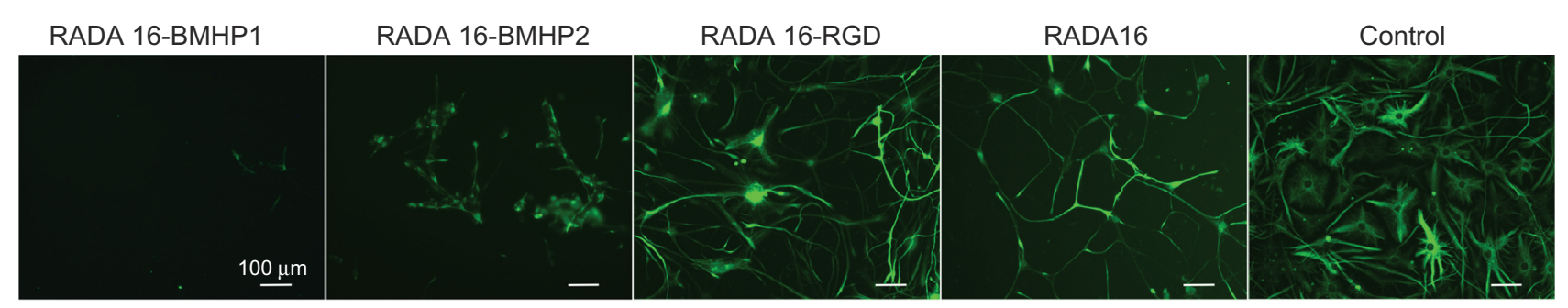

Figure 7 Immunofluorescence was performed in NSCs after 7 days of differentiation. NSCs had been proliferating for 5 days in each of the SAPs in analysis. GFAP positive cells are shown.

Abbreviations: BMHP, bone marrow homing peptide; GFAP, glial fibrillary acidic protein; NSC, neural stem cell; RGD, Arg-Gly-Asp; SAP, self-assembling peptide.

used NSCs isolated from the subventricular zone of adult mice and have successfully cultured them in 3D scaffolds made of SAP functionalized with motifs from collagen VI (RADA16-RGD) and two bone marrow homing peptides (RADA16-BMHP1 and RADA16-BMHP2). Serum-free cell culture media was used to avoid adsorption of random serum proteins within the scaffolds. We have observed that our cell culture conditions were able to support the proliferation and differentiation of adult NSCs, so that these scaffolds allow a satisfactory supply of nutrients and oxygen.

Our results show that, for all the scaffolds analyzed, NSC proliferation seems to be dependent and inversely related to the scaffold concentration, so that higher proliferation rates are obtained with lower SAP concentrations $(0.5 \%)$. The best scaffold for NSC proliferation seems to be RADA16-BMHP, although a statistically significant result was not obtained. Also, NSC proliferation in neither of the SAPs is as high as in the $2 \mathrm{D}$ control condition, and this can be explained partially by the fact that neural cells in situ have a low proliferation rate; therefore, we can claim that, in this sense, our model is similar to the in vivo conditions. After proliferating within the scaffolds for 5 days, NSCs were able to differentiate into the three major neural cellular phenotypes: neurons, astrocytes, and oligodendrocytes, and the higher number of differentiated cells was obtained for RADA16-RGD, which

3D

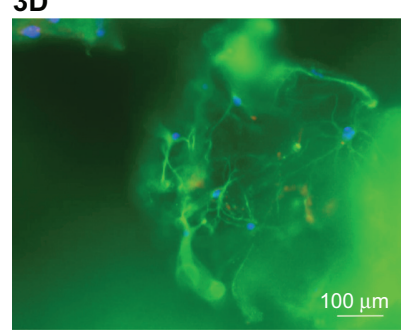

2D

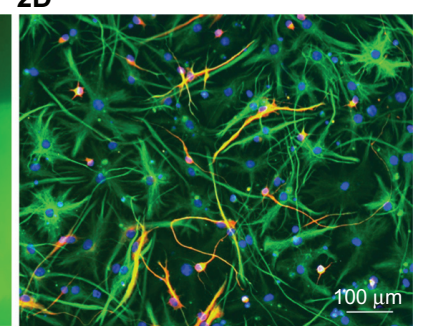

Figure 8 Differentiation of mouse NSCs in 3D and 2D conditions, after 7 days in culture. Anti-TUJI (red), anti-GFAP (green), DAPI (blue).

Abbreviations: 2D, two-dimensional; 3D, three-dimensional; DAPI, 4'-6-diamidino2-phenylindole; GFAP, glial fibrillary acidic protein; NSC, neural stem cell. demonstrates that this scaffold performs the best with regard to maintaining NSC staminality. These results indicate that functional motifs are able to direct NSC versus proliferation or differentiation.

The rheological characterization showed that, for all the SAPs analyzed, increasing their concentration resulted in an increased stiffness of the substrate. Moreover, the mean G' modulus values obtained (10-1000 $\mathrm{Pa}$ ) were within the range previously reported to be the optimum range for supporting $\mathrm{NSC}$ culture ${ }^{47}$ and to be approximately the same as native brain tissue. ${ }^{48,49}$ Our rheological results may help explain the better results achieved by the $0.5 \%$ concentrations, which have, overall, performed better than $1 \%$ and $2 \%$ concentrations. In fact, our study is in agreement with a recent study reporting that the rate of proliferation of NSCs decreased with increase in the stiffness of alginate hydrogels. ${ }^{50}$

Potential future uses and developments of this research include expansion and transplantation of stem cells for the treatment of neurodegenerative diseases, as well as testing of neural drugs and studies of gene expression, in a cell environment which is much closer to the in vivo environment than the standard Petri dish for 2D cell cultures. Indeed, deeper understanding of the mechanisms of cells behavior in such 3D scaffolds will be required for future clinical applications, and improved 3D scaffolds and cellular systems are needed for effective tissue engineering strategies. The difficulties found in the $3 \mathrm{D}$ cell culture imaging demonstrate that there will also be the need for suitable imaging techniques able to systematically analyze systems that are much more challenging than cell monolayers.

Importantly, these peptides can easily be designed ad hoc for use with different cell lineages, by using modeling and analytical techniques that are presently being developed in our laboratory. ${ }^{38,39}$ They have already demonstrated to significantly enhance osteoblast proliferation, differentiation, and $3 \mathrm{D}$ migration, ${ }^{28}$ and they have the potential to be used for a vast number of cell models. 
A

RADA16-I-BMHP1

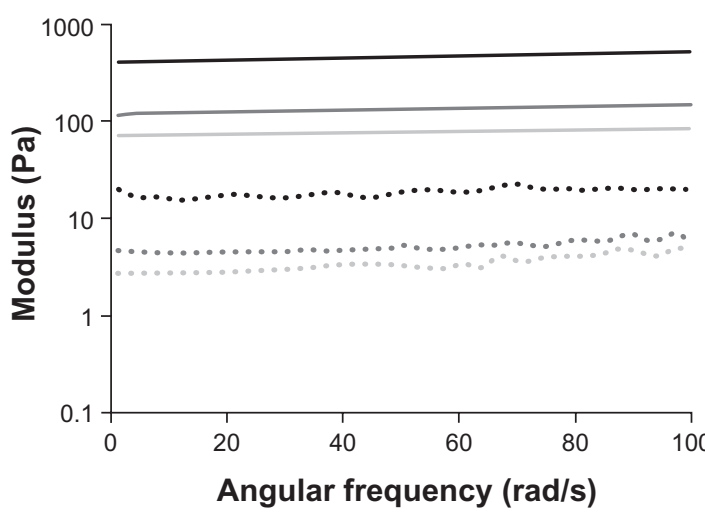

RADA16-I-RGD

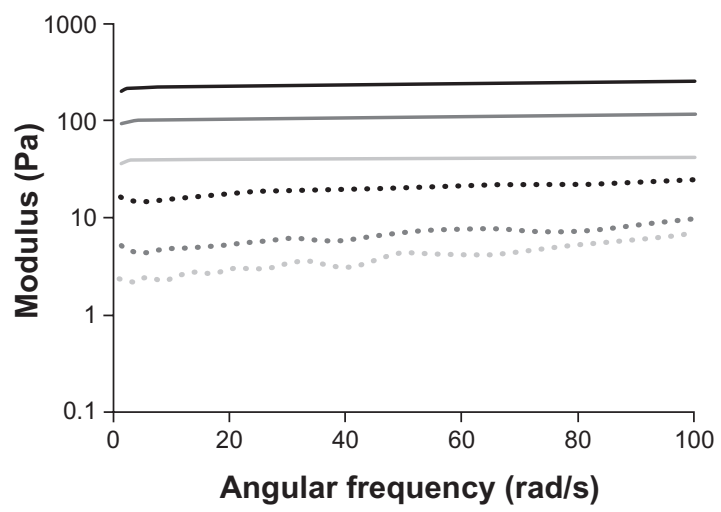

RADA16-I-BMHP2

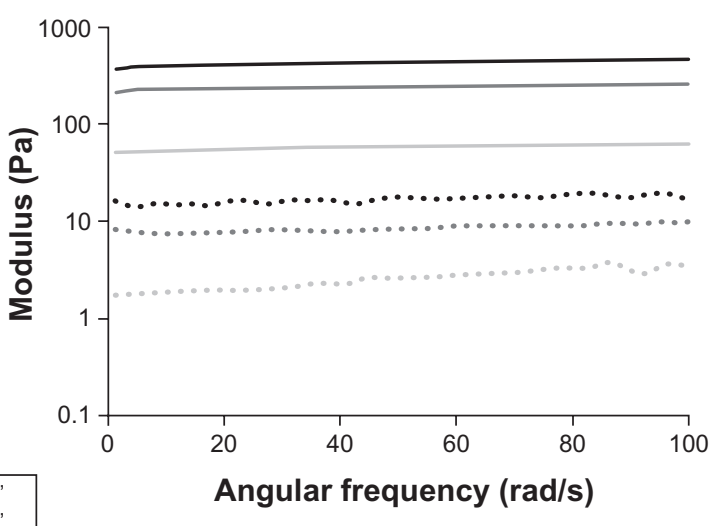

RADA16-I

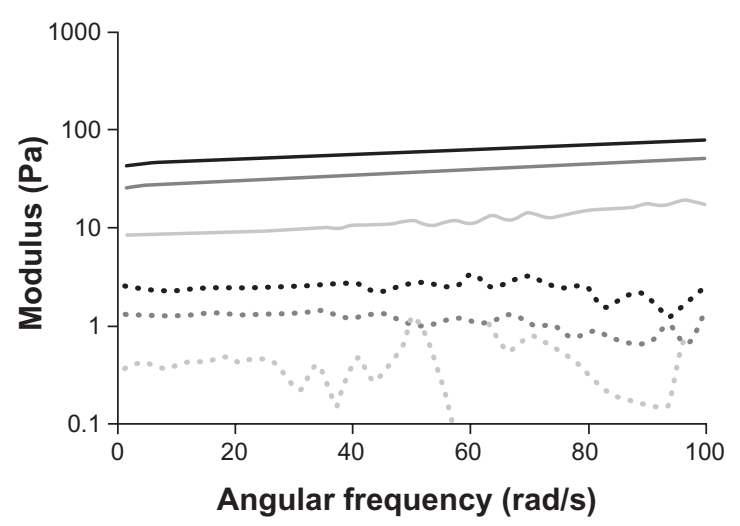

B
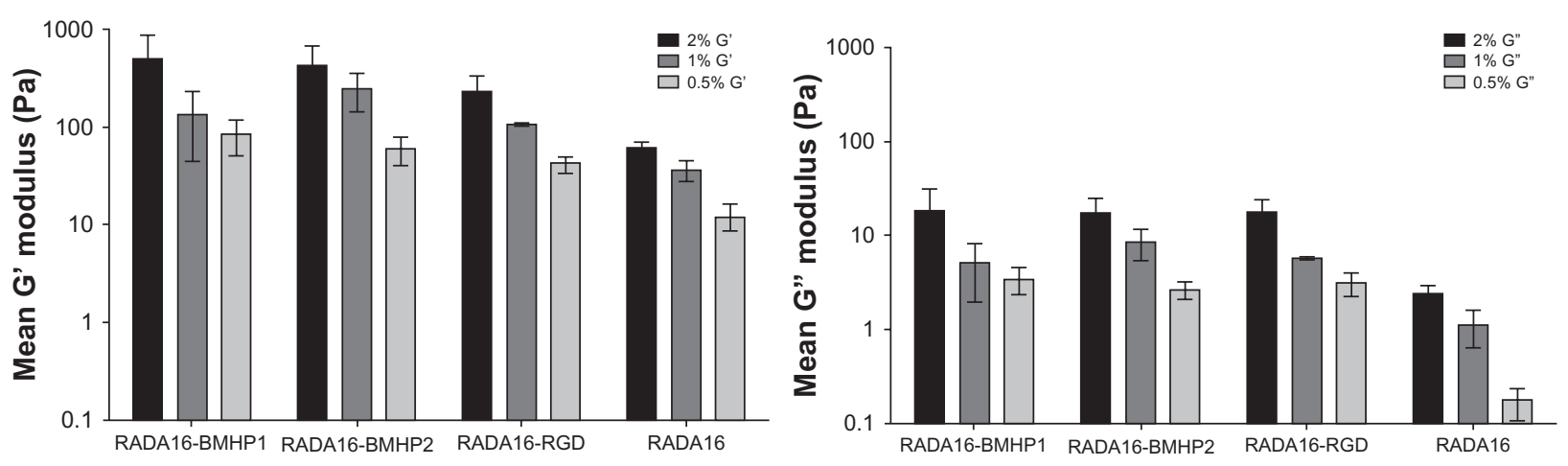

Figure 9 Rheological characterization of each SAP at concentrations of $0.5 \%$, $1 \%$, and $2 \%$. A frequency sweep test was performed on the assembled scaffold, between I and $100 \mathrm{rad} / \mathrm{s}$. A) Elastic shear modulus G' and viscous shear modulus G" values for each SAP, along the frequency sweep test. B) Mean G' and G" values for each SAP, calculated from data presented on $A$.

Abbreviations: BMHP, bone marrow homing peptide; G', elastic shear modulus; G”, viscous shear modulus; RGD, Arg-Gly-Asp; SAP, self-assembling peptide.

\section{Conclusion}

The 3D cell culture model developed proved the potential of functionalized SAPs for the culture of NSCs. These SAPs have now been shown to be highly biocompatible, able to mimic the 3D microenvironment for different cell types, and to be easily synthesized and purified ad hoc with a low batch-to-batch variability and on a large scale. These characteristics grant this $3 \mathrm{D}$ cell culture model the potential to be easily further developed and improved in order to use different cell lines to cope with different tissue engineering 
strategies and to meet clinical application standards in the near future.

\section{Acknowledgments}

The authors acknowledge CARIPLO Foundation and Regione Lombardia for providing financial resources to the project.

\section{Disclosure}

The authors report no conflicts of interest in this work.

\section{References}

1. Dalton PD, Mey J. Neural interactions with materials. Front Biosci. 2009;14:769-795

2. Horner PJ, Gage FH. Regenerating the damaged central nervous system. Nature. 2000;407(6807):963-970.

3. Nomura $\mathrm{H}$, Tator $\mathrm{CH}$, Shoichet MS. Bioengineered strategies for spinal cord repair. J Neurotrauma. 2006;23(3-4):496-507.

4. Straley KS, Foo CW, Heilshorn SC. Biomaterial design strategies for the treatment of spinal cord injuries. J Neurotrauma. 2010;27(1):1-19.

5. Owen SC, Shoichet MS. Design of three-dimensional biomimetic scaffolds. J Biomed Mater Res A. 2010;94(4):1321-1331.

6. Powers MJ, Domansky K, Kaazempur-Mofrad MR, et al. A microfabricated array bioreactor for perfused 3D liver culture. Biotechnol Bioeng. 2002;78(3):257-269.

7. Powers MJ, Janigian DM, Wack KE, Baker CS, Beer Stolz D, Griffith LG. Functional behavior of primary rat liver cells in a three-dimensional perfused microarray bioreactor. Tissue Eng. 2002;8(3):499-513.

8. Walpita D, Hay E. Studying actin-dependent processes in tissue culture. Nat Rev Mol Cell Biol. 2002;3(2):137-141.

9. Cukierman E, Pankov R, Stevens DR, Yamada KM. Taking cellmatrix adhesions to the third dimension. Science. 2001;294(5547): 1708-1712.

10. Meshel AS, Wei Q, Adelstein RS, Sheetz MP. Basic mechanism of three-dimensional collagen fibre transport by fibroblasts. Nat Cell Biol. 2005;7(2):157-164.

11. Montesano R, Matsumoto K, Nakamura T, Orci L. Identification of a fibroblast-derived epithelial morphogen as hepatocyte growth factor. Cell. 1991;67(5):901-908.

12. Montesano R, Schaller G, Orci L. Induction of epithelial tubular morphogenesis in vitro by fibroblast-derived soluble factors. Cell. 1991;66(4):697-711.

13. O'Brien LE, Zegers MM, Mostov KE. Opinion: building epithelial architecture: insights from three-dimensional culture models. Nat Rev Mol Cell Biol. 2002;3(7):531-537.

14. Zegers MM, O’Brien LE, Yu W, Datta A, Mostov KE. Epithelial polarity and tubulogenesis in vitro. Trends Cell Biol. 2003;13(4):169-176.

15. Subramanian B, Rudym D, Cannizzaro C, Perrone R, Zhou J, Kaplan DL. Tissue-engineered three-dimensional in vitro models for normal and diseased kidney. Tissue Eng Part A. 2010;16(9):2821-2831.

16. Gurkan UA, Krueger A, Akkus O. Ossifying bone marrow explant culture as a three-dimensional mechanoresponsive in vitro model of osteogenesis. Tissue Eng Part A. 2011;17(3-4):417-428.

17. Bozkurt A, Brook GA, Moellers S, et al. In vitro assessment of axonal growth using dorsal root ganglia explants in a novel three-dimensional collagen matrix. Tissue Eng. 2007;13(12):2971-2979.

18. Brannvall K, Bergman K, Wallenquist U, et al. Enhanced neuronal differentiation in a three-dimensional collagen-hyaluronan matrix. J Neurosci Res. 2007;85(10):2138-2146.

19. Levenberg S, Huang NF, Lavik E, Rogers AB, Itskovitz-Eldor J, Langer R. Differentiation of human embryonic stem cells on threedimensional polymer scaffolds. Proc Natl Acad Sci U S A. 2003; 100(22):12741-12746.
20. Peretz H, Talpalar AE, Vago R, Baranes D. Superior survival and durability of neurons and astrocytes on 3-dimensional aragonite biomatrices. Tissue Eng. 2007;13(3):461-472.

21. Zhang S. Designer self-assembling peptide nanofiber scaffolds for study of 3-D cell biology and beyond. Adv Cancer Res. 2008;99: 335-362.

22. Zhang S, Gelain F, Zhao X. Designer self-assembling peptide nanofiber scaffolds for 3D tissue cell cultures. Semin Cancer Biol. 2005;15(5): 413-420.

23. Silva GA, Czeisler C, Niece KL, et al. Selective differentiation of neural progenitor cells by high-epitope density nanofibers. Science. 2004;303(5662):1352-1355.

24. Holmes TC, de Lacalle S, Su X, Liu G, Rich A, Zhang S. Extensive neurite outgrowth and active synapse formation on self-assembling peptide scaffolds. Proc Natl Acad Sci U S A. 2000;97(12): 6728-6733.

25. Gelain F, Bottai D, Vescovi A, Zhang S. Designer self-assembling peptide nanofiber scaffolds for adult mouse neural stem cell 3-dimensional cultures. PLoS One. 2006;1:e119.

26. Semino CE, Kasahara J, Hayashi Y, Zhang S. Entrapment of migrating hippocampal neural cells in three-dimensional peptide nanofiber scaffold. Tissue Eng. 2004;10(3-4):643-655.

27. Li Q, Chau Y. Neural differentiation directed by self-assembling peptide scaffolds presenting laminin-derived epitopes. J Biomed Mater Res A. 2010;94(3):688-699.

28. Horii A, Wang X, Gelain F, Zhang S. Biological designer self-assembling peptide nanofiber scaffolds significantly enhance osteoblast proliferation, differentiation and 3-D migration. PLoS One. 2007;2(2):e190.

29. Cao Q, Benton RL, Whittemore SR. Stem cell repair of central nervous system injury. J Neurosci Res. 2002;68(5):501-510.

30. Vescovi AL, Galli R, Gritti A. The neural stem cells and their transdifferentiation capacity. Biomed Pharmacother. 2001;55(4): 201-205.

31. Foroni C, Galli R, Cipelletti B, et al. Resilience to transformation and inherent genetic and functional stability of adult neural stem cells ex vivo. Cancer Res. 2007;67(8):3725-3733.

32. Ruoslahti E, Pierschbacher MD. New perspectives in cell adhesion: RGD and integrins. Science. 1987;238(4826):491-497.

33. Nowakowski GS, Dooner MS, Valinski HM, Mihaliak AM, Quesenberry PJ, Becker PS. A specific heptapeptide from a phage display peptide library homes to bone marrow and binds to primitive hematopoietic stem cells. Stem Cells. 2004;22(6):1030-1038.

34. Ferrari D, Binda E, De Filippis L, Vescovi AL. Isolation of neural stem cells from neural tissues using the neurosphere technique. Curr Protoc Stem Cell Biol. 2010 Nov;Chapter 2:Unit2D.6.

35. Gritti A, Parati EA, Cova L, et al. Multipotential stem cells from the adult mouse brain proliferate and self-renew in response to basic fibroblast growth factor. J Neurosci. 1996;16(3):1091-1100.

36. Reynolds BA, Weiss S. Generation of neurons and astrocytes from isolated cells of the adult mammalian central nervous system. Science. 1992;255(5052):1707-1710.

37. Vescovi AL, Parati EA, Gritti A, et al. Isolation and cloning of multipotential stem cells from the embryonic human CNS and establishment of transplantable human neural stem cell lines by epigenetic stimulation. Exp Neurol. 1999;156(1):71-83.

38. Taraballi F, Campione M, Sassella A, et al. Effect of functionalization on the self-assembling propensity of beta-sheet forming peptides. Soft Matter. 2009;5:660-668.

39. Taraballi F, Natalello A, Campione M, et al. Glycine-spacers influence functional motifs exposure and self-assembling propensity of functionalized substrates tailored for neural stem cell cultures. Front Neuroengineering. 2010;3:1.

40. Yokoi H, Kinoshita T, Zhang S. Dynamic reassembly of peptide RADA16 nanofiber scaffold. Proc Natl Acad Sci U SA. 2005;102(24): 8414-8419. 
41. Zhang S, Marini DM, Hwang W, Santoso S. Design of nanostructured biological materials through self-assembly of peptides and proteins. Curr Opin Chem Biol. 2002;6(6):865-871.

42. Schense JC, Bloch J, Aebischer P, Hubbell JA. Enzymatic incorporation of bioactive peptides into fibrin matrices enhances neurite extension. Nat Biotechnol. 2000;18(4):415-419.

43. Zhang S, Holmes TC, DiPersio CM, Hynes RO, Su X, Rich A. Self-complementary oligopeptide matrices support mammalian cell attachment. Biomaterials. 1995;16(18):1385-1393.

44. Gelain F, Unsworth LD, Zhang S. Slow and sustained release of active cytokines from self-assembling peptide scaffolds. J Control Release. 2010;145(3):231-239.

45. Engler AJ, Sen S, Sweeney HL, Discher DE. Matrix elasticity directs stem cell lineage specification. Cell. 2006;126(4):677-689.
46. Ghosh K, Pan Z, Guan E, et al. Cell adaptation to a physiologically relevant ECM mimic with different viscoelastic properties. Biomaterials. 2007;28(4):671-679.

47. Saha K, Keung AJ, Irwin EF, et al. Substrate modulus directs neural stem cell behavior. Biophys J. 2008;95(9):4426-4438.

48. Flanagan LA, Ju YE, Marg B, Osterfield M, Janmey PA. Neurite branching on deformable substrates. Neuroreport. 2002;13(18): 2411-2415.

49. Lu YB, Franze K, Seifert G, et al. Viscoelastic properties of individual glial cells and neurons in the CNS. Proc Natl Acad Sci U S A. 2006;103(47):17759-17764.

50. Banerjee A, Arha M, Choudhary S, et al. The influence of hydrogel modulus on the proliferation and differentiation of encapsulated neural stem cells. Biomaterials. 2009;30(27):4695-4699.
International Journal of Nanomedicine

\section{Publish your work in this journal}

The International Journal of Nanomedicine is an international, peerreviewed journal focusing on the application of nanotechnology in diagnostics, therapeutics, and drug delivery systems throughout the biomedical field. This journal is indexed on PubMed Central, MedLine, CAS, SciSearch $\AA$, Current Contents ${ }^{\circledR} /$ Clinical Medicine,

\section{Dovepress}

Journal Citation Reports/Science Edition, EMBase, Scopus and the Elsevier Bibliographic databases. The manuscript management system is completely online and includes a very quick and fair peer-review system, which is all easy to use. Visit http://www.dovepress.com/ testimonials.php to read real quotes from published authors.

Submit your manuscript here: http://www.dovepress.com/international-journal-of-nanomedicine-journal 